\title{
Actigraphy versus Polysomnography to Identify Changes in the Sleep Patterns of Adults with Insomnia
}

\author{
Actigrafia versus Polissonografia para Identificar Alterações \\ nos Padrões de Sono de Adultos com Insônia
}

\section{Actigrafía versus Polisomnografía para Identificar Cambios en Patrones de Sueño de Adultos con Insomnia}

Andrea dos Santos Garcia ${ }^{1}$, Juliana Durães das Neves ${ }^{2}$, Solange Campos Vicentini ${ }^{3}$, Glycia de Almeida Nogueira ${ }^{4}$, Juliana Mendes Marques ${ }^{5}$, Raphael Neves Barreiros ${ }^{6}$, Cristiano Bertolossi Marta7, Roberto Carlos Lyra da Silva ${ }^{8}$, Carlos Roberto Lyra da Silva ${ }^{9}$

1.Nurse, PhD student at UNIRIO, Rio de Janeiro-RJ, Brazil. ORCID: https://orcid.org/00000002-2125-1437

2.Doctor, Psychiatry Postgraduate student at UERJ, Rio de Janeiro-RJ, Brazil. ORCID: https://orcid.org/0000-0002-7001-7

3.Doctor, PhD student at UNIRIO, Rio de Janeiro-RJ, Brazil. ORCID: https://orcid.org/0000$0002-4202-7514$

4.Nurse, PhD student at UNIRIO. Rio de Janeiro-RJ, Brazil. ORCID: https://orcid.org/00000002-2986-2427

5.Nurse, PhD student at UNIRIO, Rio de Janeiro-RJ, Brazil. ORCID: https://orcid.org/00000002-6730-9649

6.Nurse, Master's Student at UNIRIO, Rio de Janeiro-RJ, Brazil. ORCID: https://orcid.org/0000-0002-0272-3187

7.Nurse, PhD Adjunct Professor III at DFEN/FENF/UERJ, Rio de Janeiro-RJ, Brazil. ORCID: https://orcid.org/0000-0002-0635-7970

8.Nurse, Post-doctorate, Associate Professor III and Coordinator of the Post-Doctorate Program in Nursing and Biosciences at UNIRIO, Rio de Janeiro-RJ, Brazil. ORCID: https://orcid.org/0000-0002-2125-1437

9. Nurse, Post-doctorate, Director of post graduation at the Dean of Graduate Studies, Research and Innovation of PROGEPE/UNIRIO, Rio de Janeiro-RJ, Brazil. ORCID: https://orcid.org/0000-0002-4327-6272

\footnotetext{
Resumo

Introdução. A insônia é o transtorno de sono-vigília mais frequente em todo mundo. O exame complementar considerado padrão-ouro na identificação de transtornos de sono é a polissonografia. A actigrafia - método facilmente aplicável por vários dias consecutivos - no entanto, tem surgido como ferramenta alternativa. Objetivo. Avaliar a efetividade da actigrafia em comparação com a polissonografia na determinação dos padrões de sono de adultos com insônia. Método. Revisão sistemática com metanálise, na qual foram pesquisados estudos observacionais e clínicos randomizados nas bases de dados Cochrane Library, MEDLINE através do Portal PUBMED, Google Scholar e o meta-buscador TRIP DATABASE, a partir de novembro de 2019. A abordagem GRADE foi utilizada para avaliar a qualidade da evidência. A metanálise foi realizada pelo método estatístico do inverso da variância, sendo considerado o intervalo de confiança de 95\% (IC95\%). Resultados. Seis estudos foram incluídos, representando 399 pacientes. Os estudos examinaram a efetividade da actigrafia na identificação do tempo total de sono, latência, Wake After Sleep e eficiência do sono. A actigrafia esteve próxima da polissonografia apenas ao verificar a latência do sono com pequena diferença média de $-1,46$ (IC 95\%: $-9,61$ a 6,70 minutos). Os demais desfechos avaliados tiveram seus valores subestimados pela actigrafia. A qualidade da evidência foi moderada e baixa. Conclusão. As evidências para avaliar a efetividade da actigrafia ainda são limitadas - especialmente quando se pretende compará-la com a polissonografia, uma vez que
} 
os estudos encontrados apresentam limitações metodológicas, principalmente na mensuração dos resultados.

Unitermos. Actigrafia; polissonografia; Distúrbios de iniciação e manutenção do sono; Adulto

\begin{abstract}
Introduction. Insomnia is the most common sleep-wake disorder worldwide. Polysomnography is the complementary exam considered the gold standard for the identification of sleep disorders. However, Actigraphy - a method easily applicable for several consecutive days -, has emerged as an alternative tool. Objective. To evaluate the effectivity of actigraphy in comparison with polysomnography, in determining the sleep patterns of adults with insomnia. Method. Systematic review with meta-analysis, on which randomized observational and clinical studies were searched in the Cochrane Library, on MEDLINE through the PUBMED Portal, in the Google Scholar and on the TRIP DATABASE meta-search engine, from November 2019. The GRADE approach was used to evaluate the quality of the evidence. The meta-analysis was performed using the Inverse-variance weighting, considering the $95 \%$ confidence interval (95\% CI). Results. Six studies were included, representing 399 patients. The studies examine the effectivity of actigraphy in identifying the total sleep time, the latency, the Wake After Sleep and the sleep efficiency. It was noticed that the Actigraphy was close to polysomnography only when verifying sleep latency, with a small average difference of -1.46 ( $95 \% \mathrm{CI}$ : -9.61 to $6.70 \mathrm{~min}$.). The other outcomes evaluated had their values underestimated by actigraphy. The quality of the evidence was moderate and low. Conclusion. The evidence to evaluate the effectivity of actigraphy is still limited - especially when it is intended to compare it with polysomnography, since the studies found shown methodological limitations, mainly in the measurement of results.
\end{abstract}

Keywords. Actigraphy; polysomnography; Sleep initiation and maintenance disorders; Adult

\begin{abstract}
Resumen
Introducción. El insomnio es el trastorno del sueño y vigilia más común en el mundo. La polisomnografía es el examen complementario considerado el estándar de oro para la identificación de trastornos del sueño. Sin embargo, la Actigrafía - un método fácilmente aplicable durante varios días consecutivos -, se ha convertido en una herramienta alternativa. Objetivo. evaluar la efectividad de la actigrafía en comparación con la polisomnografía, para determinar los patrones de sueño de los adultos con insomnio. Método. revisión sistemática con metanálisis. A partir de noviembre de 2019, se realizaron búsquedas en estudios observacionales y clínicos aleatorios en la Biblioteca Cochrane, en las bases de datos MEDLINE a través del portal PUBMED, Google Scholar y el metabuscador TRIP DATABASE. El enfoque GRADE se utilizó para evaluar la calidad de la evidencia. El metanálisis se realizó utilizando el método estadístico de la inversa de la varianza, con un intervalo de confianza del 95\% (IC del 95\%) considerado. Resultados. Se incluyeron seis estudios, que representan a 399 pacientes. Los estudios examinaron la efectividad de la actigrafía para identificar el tiempo total de sueño, la latencia, la vigilia después del sueño y la eficiencia del sueño. La actigrafía estaba cerca de la polisomnografía solo cuando se verificaba la latencia del sueño con una pequeña diferencia media de -1,46 (IC del 95\%: -9,61 a 6,70 minutos). Los otros resultados evaluados tenían sus valores subestimados por la actigrafía. La calidad de la evidencia fue moderada y baja. Conclusión. la evidencia para evaluar la efectividad de la actigrafía aún es limitada especialmente cuando se pretende compararla con la polisomnografía -, ya que los estudios encontrados tienen limitaciones metodológicas, principalmente en la medición de los resultados.
\end{abstract}

Palabras clave. actigrafía; polisomnografía; Trastornos de iniciación y mantenimiento del sueño; Adulto

Research developed at UNIRIO, Rio de Janeiro-RJ, Brazil.

Conflict of interest: no

Recieved in: 05/01/2019

Acept in: 06/05/2020

Correspondent address: Carlos RL Silva. Email: profunirio@gmail.com 


\section{INTRODUTION}

Insomnia is the most frequent sleep-wake disorder in the world. In industrialized societies, its prevalence varies from $10 \%$ to $15 \%$ in the adult population and approximately $50 \%$ of them have a chronic course of the disorder ${ }^{1}$. Insomnia is characterized by the difficulty in initiating or maintaining sleep, which has diurnal consequences not attributable to environmental circumstances or an inadequate way of sleeping ${ }^{2}$.

According to the Fifth Edition of the Manual of Mental Disorders ${ }^{3}$ and Sateia et $\mathrm{al}^{2}$, chronic insomnia is defined by the difficulty related to sleep that appears at least three times often a week for three months consecutively. Epidemiological studies have shown that insomnia is an independent risk factor associated with an increase in the number of accidents at work, general low impairment at work, presenteeism and absenteeism ${ }^{4,5}$.

Another study also found an increase in the prevalence of hypertension associated with short sleep (less than 6 hours) in individuals with insomnia ${ }^{6}$. In addition, studies have found a strong association of insomnia with lower quality of life related to physical and mental health ${ }^{4,7}$.

The diagnosis of sleep disorders, specifically insomnia, is obtained through a good anamnesis, a subjective assessment based on questionnaires and sleep diaries and an objective assessment by the Multiple Sleep Latency Test (MSLT), the Alarm Clock Test, the Polysomnography (PSG) and the Actigraphy $(\mathrm{ACT})^{8}$. 
The MSLT consists of five PSG records obtained during the day for the diagnosis of hypersomnia of central origin and the Wake Maintenance Test is applied to identify excessive daytime sleepiness. Both tests depend on diurnal polysomnographic records ${ }^{8}$.

The PSG exam, considered the gold standard for identifying sleep disorders, is performed in laboratory for an entire night. The PSG records provide simultaneous data from electroencephalogram (EEG), electrooculogram (EOG), electromyogram (EMG), nasal airflow measurements, thoracoabdominal movements, electrocardiogram (ECG) and pulse oximetry ${ }^{8}$.

PSG is indicated for patients with suspect of respiratory disorders, neuromuscular diseases, and epileptic seizures, related to sleep ${ }^{8}$. And it should not be routinely requested for cases of uncomplicated insomnia, chronic obstructive pulmonary disease (COPD) diagnosis, patients with a defined clinical diagnosis, epileptics without complaints related to sleep, circadian rhythm disorder, restless leg syndromes and diagnosis of depression ${ }^{8}$.

The ACT, in other hand, is used to determine patterns of sleep and circadian rhythm. It can be easily used for several weeks because its format is like a wristwatch. It detects the movements for 24 hours, to measure the gross motor activity. Unlike PSG, it can be used outside the laboratory, allowing the individual to remain in their natural environment during sleep assessment ${ }^{8}$. 
Studies that compared ACT's performance with PSG's performance to assess its precision and specificity identified high precision and sensitivity. The difficulty was in terms of specificity, as ACT limited the identification of wakefulness. However, even so, these studies concluded that ACT is useful and valid for estimating total sleep time (TST) and Wake After Sleep Onset (WASO) $)^{9,10}$.

Nevertheless, in individuals with insomnia a moderate correlation was found between $\mathrm{ACT}$ and $\mathrm{PSG}^{9}$. It is likely that the reduced validity attributed to ACT in people with insomnia is due to its difficult in detecting periods of wakefulness (low sensitivity), which are higher in these individuals $\mathrm{s}^{9,11,12}$.

However, because individuals with insomnia present high variability in sleep patterns, gauging with ACT for several consecutive nights has proved to be quite useful ${ }^{13}$.

Thus, the guidelines of the American Academy of Sleep Medicine (AASM) recommend the use of ACT to evaluate patients with suspected or circadian rhythm disorders, following eight recommendations, one of which "estimate sleep parameters in adult patients with insomnia disorder". AASM recognizes that ACT does not replace PSG when laboratory tests are indicated. However, it can provide objective metrics useful in various sleep-wake disorders to aid assessment and monitoring.

Compared to PSG for evaluating sleep, in addition to being less expensive, ACT has advantages that have made it attractive to sleep researchers and physicians. This method 
can represent a useful tool to assess sleep for several consecutive days, having already been used to compare sleep parameters in different subgroups of patients.

Therefore, the purpose of this review is to evaluate the effectivity of ACT compared to PSG in determining sleep patterns of adults with insomnia.

\section{METHOD}

This study was developed as a systematic review and meta-analysis to evaluate the effectivity of ACT, having PSG as the gold standard exam. It was characterized as a study of the head-to-head type for effectivity's measurement. The following variables were considered: Sleep latency (SL); total sleep time (TST); wake after sleep onset (WASO); and sleep efficiency ( $\mathrm{SE}=\mathrm{TST} /$ time in bed).

The current revision was registered in the International Prospective Registry of Systematic Reviews (PROSPERO), with the registration number: CRD42020166901.

\section{Eligibility criteria}

Randomized clinical studies (RCTs) and observational studies that examined the effectivity of ACT in identifying sleep patterns (TTS, SL, WASO, and SE) in adult patients with insomnia, compared to PSG.

Studies written in Portuguese, Spanish, and English, involving adult patients over 18 years old with no upper age limit. Complete articles published in the last 5 years. 


\section{Research question}

The research question was based on the acronym PICO - Population: adults of both sexes with insomnia; Intervention: ACT exam; Comparator: PSG; Outcomes: SL, TST, WASO, and SE. Thus, the final PICO question was: Is ACT as reliable as PSG to identify sleep patterns in adults with insomnia?

\section{Research strategy}

The search was made in the following databases on November 2019: Cochrane Library, MEDLINE via PUBMED Portal, Google Scholar, and the TRIP DATABASE meta-search engine.

The Descriptors and their synonyms applied in the search strategy were collected from MeSH and ENTRY TERMS. The following search terms were used on MEDLINE via PUBMED and adapted to the other databases: (((polysomnography or polyssomnographies or monitoring, sleep or sleep monitoring or sonography or sonographies)) and actigraphy) and (polysomnography or polyssomnographies or monitoring, sleep or sleep monitoring or sonography or sonographies and actigraphy and sleep initiation and maintenance disorders or disorders of initiating and maintaining sleep or dims (disorders of initiating and maintaining sleep) or early awakening or awakening, early or nonorganic insomnia or insomnia, nonorganic or primary insomnia or insomnia, primary or transient insomnia or insomnia, transient or rebound 
insomnia or insomnia, rebound or secondary insomnia or insomnia, secondary or sleep initiation dysfunction or dysfunction, sleep initiation or dysfunctions, sleep initiation or sleep initiation dysfunction or sleeplessness or insomnia disorder or insomnia disorders or insomnia or insomnias or chronic insomnia or insomnia, chronic or psychophysiological insomnia or insomnia, psychophysiological).

\section{Assessment of the quality of evidence}

The GRADE system recommendations were used to evaluate the quality of the evidence, its classification (as high, moderate, low or very low) and its development ${ }^{14}$.

For this assessment, the evidence was separated into RCT and "observational studies". Following this approach, the RCTs started the evaluation with "high quality" and the observational studies with a "low quality" evidence classification. Then, the evidence was evaluated in relation to the five items that could alter its quality: the risk of bias, inconsistency, imprecision, the indirect evidence, and the publication bias ${ }^{14}$.

\section{Data analysis}

For the statistical analysis of the ACT compared to PSG the following variables were considered: TST, SL, WASO, and SE.

The meta-analysis was performed using the inverse of variance. The fixed effects model was used too and as the measure of the effect size, it was used the difference 
between averages. These were calculated and presented together with $95 \%$ confidence intervals $(95 \% \mathrm{CI})$.

The meta-analysis was carried out using the Review manager 5.3, provided by Cochrane Collaboration. And Chisquare tests were calculated to estimate the heterogeneity.

\section{RESULTS}

The results found on the databases were reunited in a reference manager, from which 445 articles were retrieved. The analysis and judgment of the documents were made by two independent judges, who decided from reading the papers' title and summary which ones should be included, considering the eligibility criteria. Duplicate studies were eliminated, leaving 386 articles to be analyzed. Then the eligibility criteria were applied, and 44 conflicts arose that were resolved by a third judge, resting 13 articles for complete reading by the end of the process. The entire inclusion and exclusion process considered the proposed steps by PRISMA FLOW ${ }^{15}$, which can be seen in Figure 1.

\section{Main characteristics of the included studies}

The following information was extracted from the manuscripts: reference, design, population, intervention, outcome, results, and limitations described in Figure 2 . The six studies included evaluated the performance of ACT in comparison with PSG (head-to-head) for the outcomes 
covered in this study, namely: three observational studies and three randomized controlled clinical trials.

Figure 1. Articles selection on PRISMA Flow Diagram.

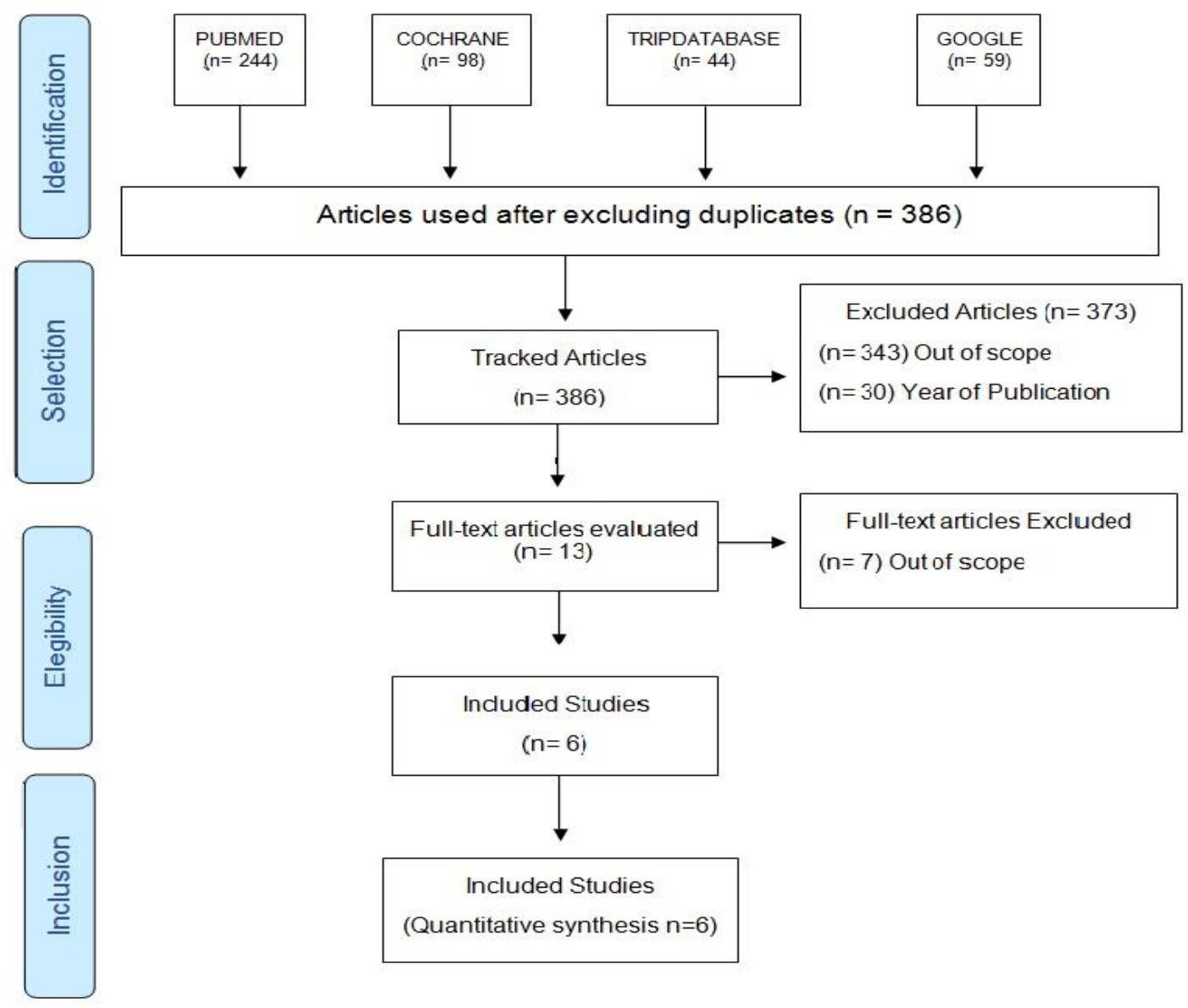

\section{Metanalysis and interpretation of clinical significance}

The meta-analysis was carried out with the six included studies, gathering data for each result of interest in the PICO question. All meta-analysis was performed using the fixed effects model, with the results displayed in a forest plot. Below, the summaries of the identified evidence and the statistical analyzes performed are detailed. 


\section{Total Sleep Time (TST)}

The meta-analysis of the six studies compared ACT with PSG for the assessment of TST in patients with insomnia. See Figure 3. It showed a significant result suggesting that there is a difference between the average time, $46 \mathrm{~min}$. greater in PSG in the measurement of TST, when compared to ACT (with average of $46 \mathrm{~min}, 95 \% \mathrm{CI}: 41.24$ to 50.75 ). Thus, TTS was underestimated by ACT. The quality of the evidence was moderate, and the heterogeneity was significant with a $70 \%$ level.

\section{Sleep Latency (SL)}

In the analysis for the evaluation of $S L$, on Figure 4, it suggests that there is no significant difference in the measurement of SL when using ACT and PSG, as it showed an average of -1.46 (95\% CI: -9.61 on $6.70 \mathrm{~min})$. This small difference indicates that ACT and PSG provide similar information to assess SL. The quality of the evidence was downgraded due to the imprecision and the heterogeneity was significant with an $85 \%$ level.

\section{Wake After Sleep Onset (WASO)}

The meta-analysis of the studies that compared ACT to PSG for the assessment of WASO, detailed on Figure 5, showed a confidence interval with a possible mean of -32.61 minutes ( $95 \% \mathrm{CI}$ : -34.98 on $-30.24 \mathrm{~min}$ ). As a result, WASO was underestimated by ACT so ACT and PSG provide different measurements of this parameter. The quality of the 
evidence was moderate, and the heterogeneity was significant with a $94 \%$ level.

\section{Sleep Efficiency (SE)}

The analysis comparing actigraphy with PSG to assess SE, on Figure 6, showed a clinically insignificant range, with an average of $3.66 \%$ ( $95 \% \mathrm{CI}: 3.02$ on $4.30 \mathrm{~min}$ ). This range indicates that ACT underestimated WASO compared to PSG. The quality of the evidence was moderate, and the heterogeneity was significant with an $81 \%$ level.

\section{Evidence quality}

On Tables 1 and 2 are show the quality of the evidence for each outcome. Quality was classified as "low" due to inaccuracy (wide confidence interval); and "Moderate", due to the risk of bias (some studies presented other comorbidities concomitant with insomnia; they inserted subjective reports in the actigraphy; or they used ACT for several days and PSG only for one night) and inconsistency (high heterogeneity). 
Figure 2. Summary of studies included in the study.

\begin{tabular}{|c|c|c|c|c|}
\hline REFERENCES & $\begin{array}{l}\text { STUDY } \\
\text { DESIGN }\end{array}$ & INTERVENTIONS & OUTCOMES & RESULTS \\
\hline $\begin{array}{l}\text { ACT scoring for } \\
\text { sleep outcome } \\
\text { measures in } \\
\text { chronic } \\
\text { obstructive } \\
\text { pulmonary } \\
\text { disease }^{17} \text {. }\end{array}$ & $\begin{array}{l}\text { RCT, } \\
\text { conducted } \\
\text { with } 50 \\
\text { participants } \\
\text { recruited in } \\
\text { the Chicago } \\
\text { area, with } \\
\text { mild to severe } \\
\text { COPD and } \\
\text { insomnia. }\end{array}$ & $\begin{array}{l}\text { Compares } \\
\text { standard and } \\
\text { custom settings of } \\
\text { ACT with PSG to } \\
\text { measure sleep } \\
\text { results. }\end{array}$ & $\begin{array}{l}\text { Compared } \\
\text { data from } \\
\text { personalized } \\
\text { ACT (5,10,15 } \\
\text { immobile min. } \\
\text { and activity } \\
\text { thresholds of } \\
0,5,10,20,40) \\
\text { with PSG in } \\
\text { patients with } \\
\text { COPD and } \\
\text { insomnia. }\end{array}$ & 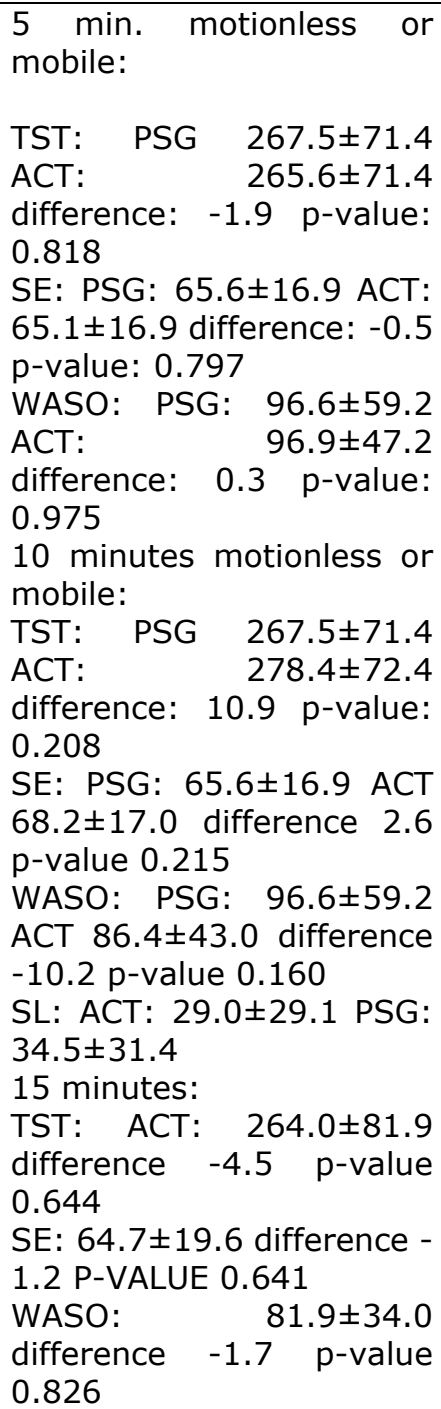 \\
\hline
\end{tabular}

Limitations: The lights turned off at the times recorded by the PSG coach were used to define the rest interval during the scoring of the ACT.

\begin{tabular}{|c|c|c|c|c|}
\hline $\begin{array}{l}\text { Measuring } \\
\text { treatment } \\
\text { outcomes } \\
\text { comorbid } \\
\text { insomnia } \\
\text { fibromyalgia: and } \\
\text { concordance of } \\
\text { subjective and } \\
\text { objective } \\
\text { assessments }{ }^{18} \text {. }\end{array}$ & $\begin{array}{l}\text { RCT, } \\
\text { performed } \\
\text { with } 113 \\
\text { patients with } \\
\text { fibromyalgia } \\
\text { and insomnia } \\
\text { who were } \\
\text { randomized } \\
\text { to } 39 \text { patients } \\
\text { on Cognitive- } \\
\text { Behavioral } \\
\text { Therapy for } \\
\text { Insomnia } \\
\text { (CBT-I); } 37 \\
\text { for CBT for } \\
\text { pain; and } 37 \\
\text { waiting list } \\
\text { controls. }\end{array}$ & $\begin{array}{l}\text { CBT, CBT-I, CBT } \\
\text { for pain, or waitlist } \\
\text { control. }\end{array}$ & $\begin{array}{l}\text { Evaluation of } \\
\text { the baseline } \\
\text { agreement of } \\
\text { ACT in relation } \\
\text { to diaries and } \\
\text { outpatient } \\
\text { PSG and the } \\
\text { investigation } \\
\text { of whether the } \\
\text { treatment } \\
\text { effects were } \\
\text { detected by } \\
\text { the } \\
\text { assessment } \\
\text { methods } \\
\text { (CBT-I; CBT). }\end{array}$ & $\begin{array}{l}\text { TTS: ACT } 400.39 \pm 119.61 \\
\text { PSG: } 380.83 \pm 102.56 \\
\text { SL: ACT 46.93 } \\
\text { PSG: } 25.73 \pm 41.63 \\
\text { SE: ACT: } 79.46 \pm 10.58 \\
\text { PSG: } 78.57 \pm 12.07 \\
\text { WASO: ACT } 45.77 \pm 31.37 \\
\text { PSG: } 78.54 \pm 48.74 . \\
\text { The relationship between } \\
\text { ACT and PSG was not } \\
\text { significant ( } r=0.08, p= \\
0.45 \text { ) }\end{array}$ \\
\hline
\end{tabular}

Limitations: PSG was performed in just one night and ACT for two consecutive weeks. 


\begin{tabular}{|c|c|c|c|c|}
\hline $\begin{array}{l}\text { Relation between } \\
\text { ambulatory ACT } \\
\text { and laboratory } \\
\text { PSG in insomnia } \\
\text { practice and } \\
\text { research }^{11} \text {. }\end{array}$ & $\begin{array}{l}\text { Observational } \\
\text { study with } 30 \\
\text { participants } \\
\text { who were } \\
\text { instructed to } \\
\text { use the ACT } \\
\text { for } 7 \\
\text { consecutive } \\
\text { days. }\end{array}$ & $\begin{array}{l}\text { Evaluates several } \\
\text { nights with ACT at } \\
\text { home, compared } \\
\text { to just one night of } \\
\text { PSG in the } \\
\text { laboratory. Also } \\
\text { soughting to } \\
\text { assess sleep at } \\
\text { home after } \\
\text { performing PSG in } \\
\text { the laboratory. }\end{array}$ & $\begin{array}{l}\text { Demonstration } \\
\text { of the } \\
\text { parameters } \\
\text { that can be } \\
\text { expected in } \\
\text { ACT, when } \\
\text { compared to a } \\
\text { single night } \\
\text { with PSG, in } \\
\text { the laboratory. }\end{array}$ & 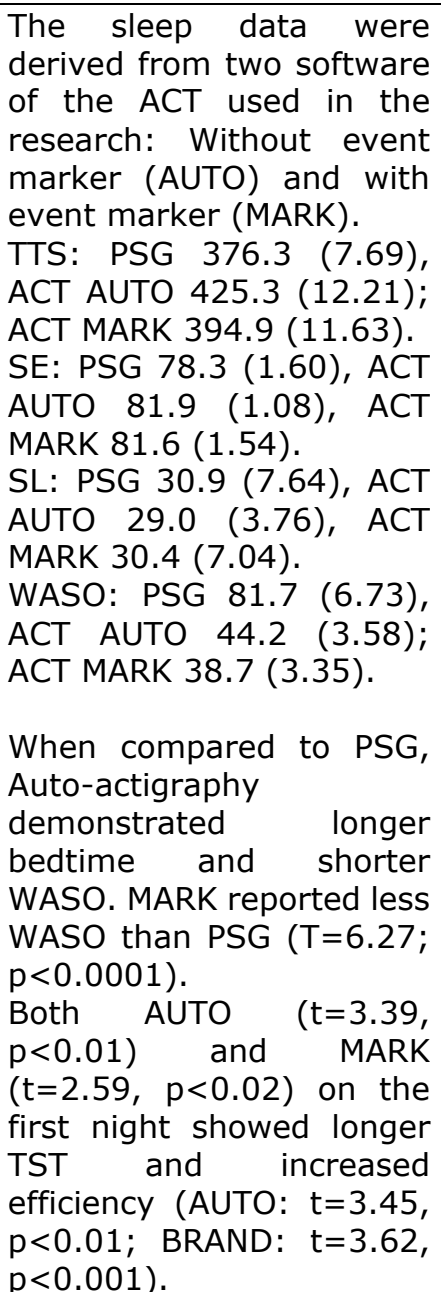 \\
\hline
\end{tabular}

Limitations: Event markers were used in the ACT, when users forgot to mark them, they were placed manually, according to a subjective report.

\begin{tabular}{|c|c|c|c|c|}
\hline 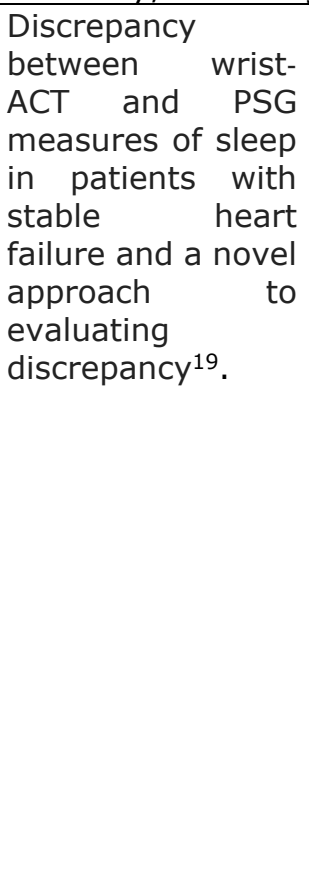 & $\begin{array}{l}\text { Observational } \\
\text { study, carried } \\
\text { out with } 173 \\
\text { patients with } \\
\text { severe Heart } \\
\text { Failure (HF) } \\
\text { and insomnia, } \\
\text { including } 155 \\
\text { participants } \\
\text { who used one } \\
\text { night of ACT } \\
\text { and PSG. }\end{array}$ & $\begin{array}{ll}\text { Evaluates } & \text { the } \\
\text { agreement } & \text { or } \\
\text { discrepancy } & \\
\text { between ACT } & \text { and } \\
\text { PSG. }\end{array}$ & $\begin{array}{l}\text { Evaluation of } \\
\text { the agreement } \\
\text { or discrepancy } \\
\text { between ACT } \\
\text { and PSG in a } \\
\text { group of adult } \\
\text { patients with } \\
\text { Stable HF with } \\
\text { sleep } \\
\text { fragmentation. } \\
\text { Examines and } \\
\text { proposes } \\
\text { brings a } \\
\text { proposal for a } \\
\text { new approach } \\
\text { to evaluate the } \\
\text { discrepancy } \\
\text { between these } \\
\text { measures and } \\
\text { their } \\
\text { correlations } \\
\text { with risk } \\
\text { factors. }\end{array}$ & $\begin{array}{l}\text { The average discrepancies } \\
\text { between ACT and PSG in } \\
\text { TST ( } 50.91 \pm 6.92 \text { min), SE } \\
(8.82 \pm 1.36) \text {, SL (- } \\
9.44 \pm 3.38 \mathrm{~min}) \text { and in } \\
\text { WASO }(-43.56 \pm 5.72 \mathrm{~min}) \\
\text { were significant }(p<0.0001 \\
\text { I mean discrepancy }>0) \\
\text { and, with the exception of } \\
\mathrm{SL}(p=0.1657) \text { and SE } \\
(p=0.0746) \text {, } \\
\text { discrepancies were present } \\
\text { in both age groups. } \\
\text { The average discrepancies } \\
\text { were higher in the older } \\
\text { participants than in the } \\
\text { younger ones for all sleep } \\
\text { measures, except for SL } \\
\text { ( } p=0.9099) \text {. }\end{array}$ \\
\hline
\end{tabular}

Limitations: It does not make it clear whether all individuals had insomnia or only sleep complaints. 


\begin{tabular}{|c|c|c|c|c|}
\hline $\begin{array}{l}\text { Validity of } A C T \text { in } \\
\text { young adults with } \\
\text { insomnia20. }\end{array}$ & $\begin{array}{l}\text { RCT, } \\
\text { conducted } \\
\text { with } 21 \text { young } \\
\text { adults }>18 \\
\text { years of age } \\
\text { with } \\
\text { insomnia, } \\
\text { recruited in } \\
\text { the } \\
\text { psychology } \\
\text { degree. }\end{array}$ & $\begin{array}{l}\text { Validates ACT for } \\
\text { the use in young } \\
\text { adults } \quad \text { with } \\
\text { insomnia, } \\
\text { compared to PSG. }\end{array}$ & $\begin{array}{l}\text { The validation } \\
\text { of ACT for } \\
\text { sleep } \\
\text { assessment as } \\
\text { a proposal for } \\
\text { young adults } \\
\text { who suffer } \\
\text { from } \\
\text { insomnia. }\end{array}$ & $\begin{array}{l}\text { Only significant mean } \\
\text { difference }(p<0.01) \text { was } \\
\text { found between } A C T \text { and } \\
\text { PSG in the number of } \\
\text { awakenings ( }[20]=9.39 \text {, } \\
p<0.001) \text {. No difference } \\
\text { was found in the other } \\
\text { sleep measures. }\end{array}$ \\
\hline \multicolumn{5}{|c|}{ Limitations: Compared eight nights of ACT with 01 night of PSG. } \\
\hline $\begin{array}{l}\text { Discordant sleep } \\
\text { parameters } \\
\text { among ACT, PSG, } \\
\text { and perceived } \\
\text { sleep in patients } \\
\text { with } \\
\text { disordered sleep- } \\
\text { breathing in } \\
\text { comparison with } \\
\text { patients with } \\
\text { chronic insomnia } \\
\text { disorder }{ }^{21} \text {. }\end{array}$ & $\begin{array}{l}\text { Observational } \\
\text { study, } \\
\text { included } 31 \\
\text { participants } \\
\text { with Sleep } \\
\text { Disordered } \\
\text { Breathing } \\
\text { (SDB) and } 30 \\
\text { Chronic } \\
\text { Insomnia (CI) } \\
\text { Participants } \\
\text { underwent } \\
\text { ACT } \\
\text { monitoring } \\
\text { concomitantly } \\
\text { on PSG night }\end{array}$ & $\begin{array}{l}\text { Investigates the } \\
\text { correlation and } \\
\text { variation between } \\
\text { PSG r sleep } \\
\text { parameters and } \\
\text { ACT }\end{array}$ & $\begin{array}{l}\text { Showing as } \\
\text { sleep } \\
\text { parameters } \\
\text { vary between } \\
\text { PSG, ACT, and } \\
\text { perceived } \\
\text { sleep } \\
\text { individuals in } \\
\text { with SDB and } \\
\text { the } \\
\text { correlations } \\
\text { between PSG } \\
\text { and ACT in the } \\
\text { SDB and CI } \\
\text { groups. }\end{array}$ & $\begin{array}{l}\text { Patients with HF: TTS } \\
\text { measured by PSG was } \\
368.3 \pm 51.30 \text { and ACT } \\
396.7 \pm 50.45 ; \text { SL by PSG } \\
\text { was } 11.7 \pm 13.98 \text { and ACT } \\
\text { was } 8.7 \pm 14.60 ; \text { WASO by } \\
\text { PSG was } 61.6 \pm 33.36 \text { and } \\
\text { ACT } 27.6 \pm 22.49 ; \text { and SE } \\
\text { by PSG was } 83.3 \pm 8.06 \text { and } \\
\text { by ACT } 89.6 \pm 6.22 \text {. All } \\
\text { parameters in the IC group } \\
\text { were significantly } \\
\text { correlated between PSG } \\
\text { and ACT (ICC }=0.813 \text {, TST } \\
0.695 \text {, SL } 0.627 \text {, WASO } \\
0.629 \text {, and SE } p<0.005) \text {. }\end{array}$ \\
\hline \multicolumn{5}{|c|}{ Limitations: only one night's sleep was evaluated. } \\
\hline \multicolumn{5}{|c|}{$\begin{array}{l}\mathrm{ACT}=\text { actigraphy; } \mathrm{RCT}=\text { randomized controlled trial; } \mathrm{COPD}=\text { chronic obstructive pulmonary disease; } \\
\mathrm{PSG}=\text { polysomnography; TST=total sleep time; } \mathrm{SE}=\text { sleep efficiency; WASO=waking up after sleep onset; } \mathrm{SL}=\text { sleep } \\
\text { latency }\end{array}$} \\
\hline
\end{tabular}

Figure 3. The effectivity of ACT with PSG for TST, in minutes, in patients with insomnia.

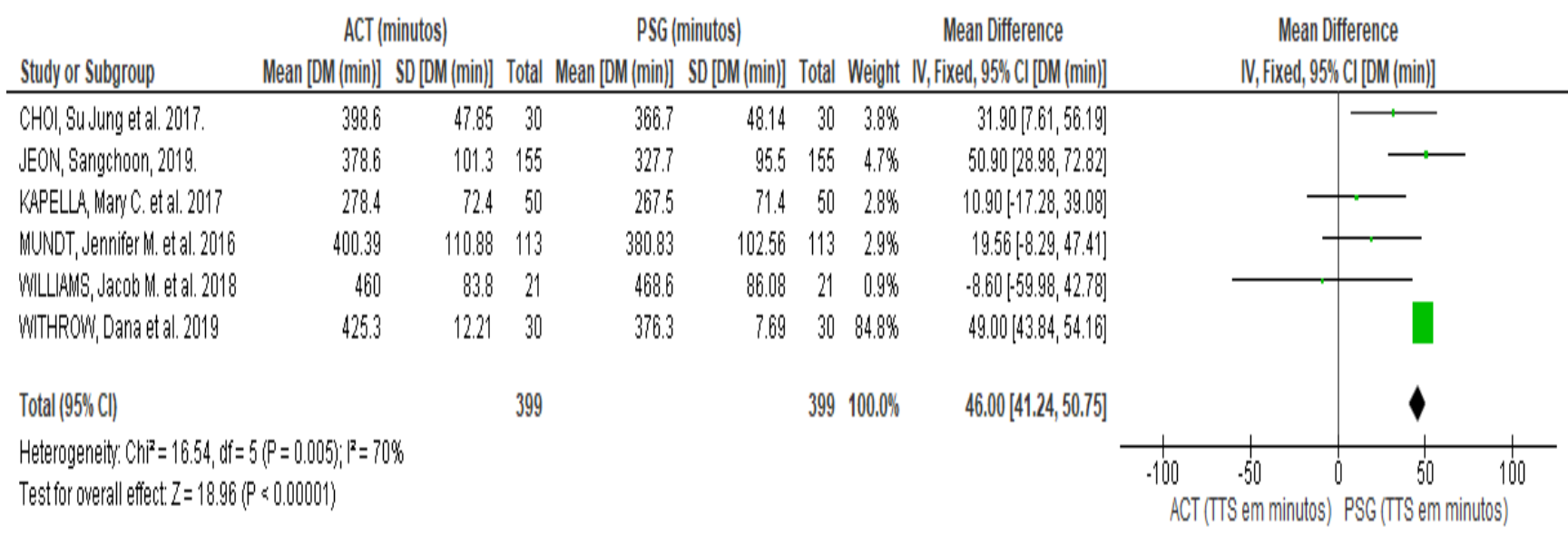


Figure 4. ACT effectivity compared to PSG for SL assessment, in minutes, in patients with insomnia.

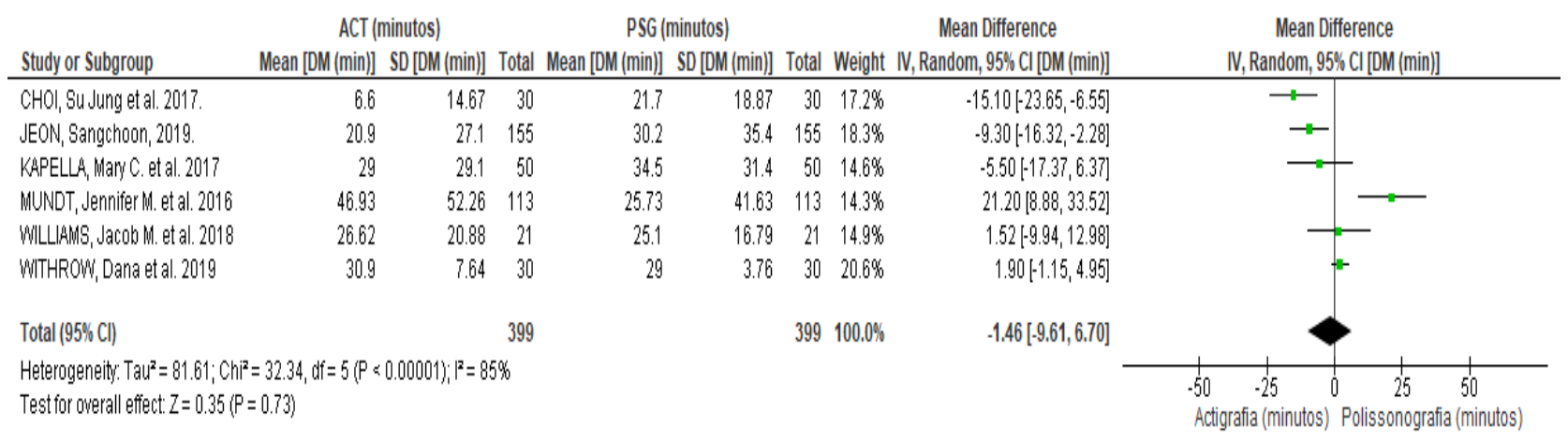

Figure 5. ACT effectivity compared to PSG for WASO assessment, in minutes, in patients with insomnia.

\begin{tabular}{|c|c|c|c|c|c|c|c|c|c|c|c|c|}
\hline Study or Subgroup & \multicolumn{3}{|c|}{ ACT (minutos) } & \multicolumn{3}{|c|}{ PSG (minutos) } & \multicolumn{2}{|c|}{ Mean Difference } & \multicolumn{4}{|c|}{$\begin{array}{c}\text { Mean Difference } \\
\text { IV, Fixed, } 95 \% \text { Cl [DM (min)] }\end{array}$} \\
\hline $\mathrm{CHOI}$, Su Jung et al. 2017. & 30.6 & 21.26 & 30 & 67.9 & 33.41 & 30 & $2.8 \%$ & $-37.30[-51.47,-23.13]$ & & - & & \\
\hline JEON, Sangchoon, 2019. & 20.9 & 27.1 & 155 & 35.4 & 35.4 & 155 & $11.4 \%$ & $-14.50[-21.52,-7.48]$ & & $\rightarrow$ & & \\
\hline KAPELLA, Mary C. et al. 2017 & 86.4 & 43 & 50 & 96.6 & 59.2 & 50 & $1.4 \%$ & $-10.20[-30.48,10.08]$ & & & & \\
\hline MUNDT, Jennifer M. et al. 2016 & 45.77 & 31.37 & 113 & 78.54 & 48.74 & 113 & $4.9 \%$ & $-32.77[-43.46,-22.08]$ & & $\longrightarrow$ & & \\
\hline WILLIAMS, Jacob M. et al. 2018 & 26.62 & 20.88 & 21 & 25.1 & 16.79 & 21 & $4.3 \%$ & $1.52[-9.94,12.98]$ & & & & \\
\hline WITHROW, Dana et al. 2019 & 44.2 & 3.58 & 30 & 81.7 & 6.73 & 30 & $75.3 \%$ & $-37.50[-40.23,-34.77]$ & & & & \\
\hline Total $(95 \%$ Cl) & & & 399 & & & 399 & $100.0 \%$ & $-32.61[-34.98,-30.24]$ & & 1 & & \\
\hline $\begin{array}{l}\text { Heterogeneity: } \mathrm{Chi}^{2}=77.11, \mathrm{df}= \\
\text { Test for overall effect: } Z=27.00\end{array}$ & $\begin{array}{l}(P<0.00001) ; 1^{2}= \\
<0.00001)\end{array}$ & $94 \%$ & & & & & & & -100 & $\begin{array}{c}-50 \\
\text { Actigrafia (minutos) }\end{array}$ & Polissonogra & rafia (minutos) \\
\hline
\end{tabular}

Figure 6. ACT effectivity compared to PSG for SE assessment, in minutes, in patients with insomnia.

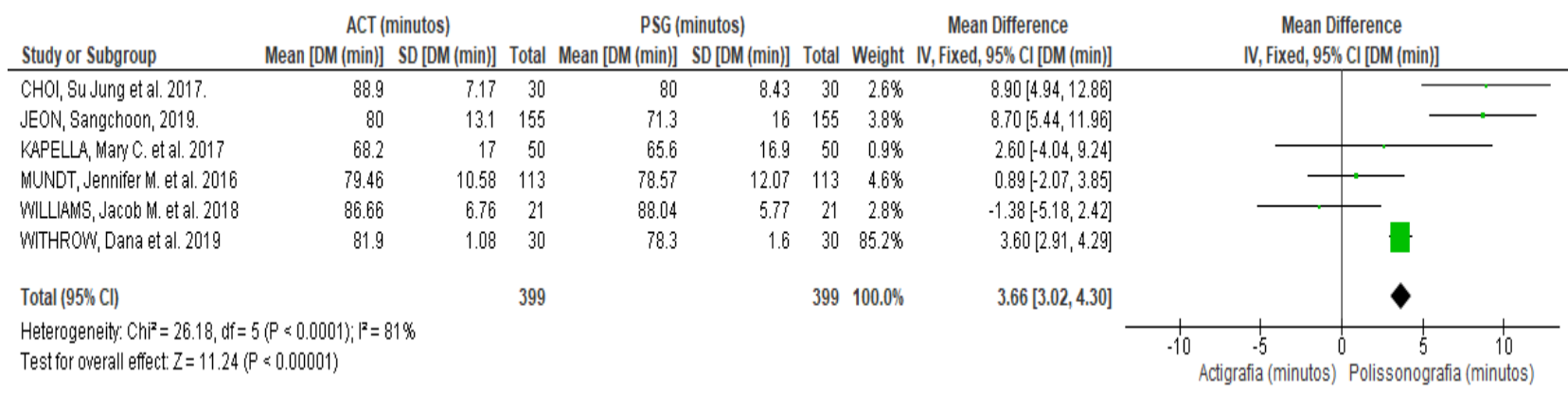


Table 1. Profile of the quality of evidence for the results of randomized studies adapted from GRADE.

\begin{tabular}{|c|c|c|c|c|c|c|c|c|c|}
\hline \multicolumn{10}{|c|}{ References ${ }^{17,18,20}$} \\
\hline \multicolumn{5}{|c|}{ Certainty assessment } & \multicolumn{5}{|c|}{ Results } \\
\hline \multirow{2}{*}{$\begin{array}{c}\text { Participants } \\
\text { (studies) } \\
\text { Follow-up }\end{array}$} & \multirow{2}{*}{$\begin{array}{l}\text { Risk of } \\
\text { bias }\end{array}$} & \multirow{2}{*}{ Inconsistence } & \multirow{2}{*}{$\begin{array}{l}\text { Indirect } \\
\text { evidence }\end{array}$} & \multirow{2}{*}{ Imprecision } & \multirow{2}{*}{$\begin{array}{c}\text { Publication } \\
\text { bias }\end{array}$} & \multirow{2}{*}{$\begin{array}{l}\text { Overall certainty } \\
\text { of evidence }\end{array}$} & \multicolumn{2}{|c|}{ Study event rates $(\%)$} & \multirow{2}{*}{$\begin{array}{l}\text { Relative effect } \\
(95 \% \mathrm{CI})\end{array}$} \\
\hline & & & & & & & With PSG & With ACT & \\
\hline \multicolumn{10}{|c|}{ Total Sleep Time } \\
\hline $\begin{array}{c}368 \\
\text { (3 RCTs) }\end{array}$ & Serious $^{f}$ & serious $a, b$ & not serious ${ }^{c}$ & not serious & $\begin{array}{l}\text { all potential } \\
\text { confounding } \\
\text { factors would } \\
\text { suggest a } \\
\text { spurious } \\
\text { effect, and } \\
\text { even then, no } \\
\text { effect was } \\
\text { observed. }\end{array}$ & $\begin{array}{c}\oplus \oplus \oplus \bigcirc \\
\text { MODERATE }\end{array}$ & $\begin{array}{c}184 / 184 \\
(100.0 \%)\end{array}$ & $\begin{array}{l}184 / 184 \\
(100.0 \%)\end{array}$ & $\begin{array}{c}46.00 \\
(41.24 \text { to } 50.75)\end{array}$ \\
\hline \multicolumn{10}{|c|}{ Sleep Latency } \\
\hline $\begin{array}{c}368 \\
\text { (3 RCTs) }\end{array}$ & serious ${ }^{d, f}$ & serious ${ }^{a, b}$ & not serious & serious $^{e}$ & $\begin{array}{c}\text { all potential } \\
\text { confounders } \\
\text { would reduce } \\
\text { the } \\
\text { demonstrated } \\
\text { effect. }\end{array}$ & $\begin{array}{c}\oplus \oplus \bigcirc \bigcirc \\
\text { LOW }\end{array}$ & $\begin{array}{l}184 / 184 \\
(100.0 \%)\end{array}$ & $\begin{array}{c}184 / 184 \\
(100.0 \%)\end{array}$ & $\begin{array}{c}-1.46-- \\
(-9.61 \text { to } 6.70)\end{array}$ \\
\hline
\end{tabular}


Table 1 (cont.). Profile of the quality of evidence for the results of randomized studies adapted from GRADE.

Wake after sleep onset (WASO)

\begin{tabular}{|c|c|c|c|c|c|c|c|c|c|}
\hline $\begin{array}{c}368 \\
\text { (3 RCTs) }\end{array}$ & $\underset{a, d, f}{\text { serious }}$ & serious ${ }^{b}$ & not serious & not serious & $\begin{array}{c}\text { all potential } \\
\text { confounders } \\
\text { would reduce } \\
\text { the } \\
\text { demonstrated } \\
\text { effect }\end{array}$ & $\begin{array}{c}\oplus \oplus \oplus \bigcirc \\
\text { MODERATE }\end{array}$ & $\begin{array}{c}184 / 184 \\
(100.0 \%)\end{array}$ & $\begin{array}{c}184 / 184 \\
(100.0 \%)\end{array}$ & $\begin{array}{c}-32.61-- \\
(-34.98 \text { to }-30.24)\end{array}$ \\
\hline
\end{tabular}

Sleep Efficiency

\begin{tabular}{|c|c|c|c|c|c|c|c|c|c|}
\hline $\begin{array}{c}368 \\
(3 \mathrm{RCTs})\end{array}$ & $\underset{a, d, f}{\text { serious }}$ & serious $^{b}$ & not serious & not serious & $\begin{array}{l}\text { all potential } \\
\text { confunding } \\
\text { factors would } \\
\text { suggest a } \\
\text { spurious effect } \\
\text { and even } \\
\text { then, no } \\
\text { effects were } \\
\text { observed. }\end{array}$ & $\begin{array}{c}\oplus \oplus \oplus \bigcirc \\
\text { MODERATE }\end{array}$ & $\begin{array}{c}184 / 184 \\
(100.0 \%)\end{array}$ & $\begin{array}{c}184 / 184 \\
(100.0 \%)\end{array}$ & $\begin{array}{c}3.66-- \\
(3.02 \text { to } 4.30)\end{array}$ \\
\hline
\end{tabular}

CI: Confidence interval. A. Patients had other comorbidites other than insomnia; B. heterogeneity greater than $50 \%$ was fou 
Table 2. Profile of the quality of evidence for the results of observational studies, adapted from GRADE.

\begin{tabular}{|c|c|c|c|c|c|c|c|c|c|}
\hline \multicolumn{10}{|c|}{ References $11,19,21$} \\
\hline \multicolumn{5}{|c|}{ Certainty Assessment } & \multicolumn{5}{|c|}{ Results } \\
\hline \multirow{2}{*}{$\begin{array}{l}\text { Participants } \\
\text { (studies) } \\
\text { Follow-up }\end{array}$} & \multirow{2}{*}{$\begin{array}{c}\text { Risk of } \\
\text { bias }\end{array}$} & \multirow{2}{*}{ Inconsistency } & \multirow{2}{*}{$\begin{array}{l}\text { Indirect } \\
\text { evidence }\end{array}$} & \multirow{2}{*}{ Imprecision } & \multirow{2}{*}{$\begin{array}{c}\text { Publication } \\
\text { bias }\end{array}$} & \multirow{2}{*}{$\begin{array}{l}\text { Overall } \\
\text { certainty of } \\
\text { evidence }\end{array}$} & \multicolumn{2}{|c|}{ Study event rates $(\%)$} & \multirow{2}{*}{$\begin{array}{l}\text { Relative effect } \\
\quad(95 \% \mathrm{CI})\end{array}$} \\
\hline & & & & & & & With PSG & With ACT & \\
\hline \multicolumn{10}{|c|}{ Total Sleep Time } \\
\hline $\begin{array}{c}430 \\
\begin{array}{c}\text { (3 observational } \\
\text { studies) }\end{array}\end{array}$ & Serious ${ }^{\mathrm{e}}$ & serious ${ }^{a, b}$ & not serious & not serious & $\begin{array}{l}\text { all potential } \\
\text { confounding } \\
\text { factors would } \\
\text { suggest a } \\
\text { spurious effect, } \\
\text { and even then, } \\
\text { no effect was } \\
\text { observed. }\end{array}$ & $\begin{array}{c}\oplus \oplus \oplus \bigcirc \\
\text { MODERATE }\end{array}$ & $\begin{array}{c}215 / 215 \\
(100.0 \%)\end{array}$ & $\begin{array}{c}215 / 215 \\
(100.0 \%)\end{array}$ & $\begin{array}{c}-46.00-- \\
(41.24 \text { to } 50.75)\end{array}$ \\
\hline
\end{tabular}

Sleep Latency

\begin{tabular}{|c|c|c|c|c|c|c|c|c|c|}
\hline $\begin{array}{c}430 \\
\text { (3 observational } \\
\text { studies) }\end{array}$ & $\underset{a, c, e}{\text { serious }}$ & serious $^{b}$ & not serious & serious $^{d}$ & $\begin{array}{l}\text { all potential } \\
\text { confounding } \\
\text { factors would } \\
\text { suggest a } \\
\text { spurious effect, } \\
\text { and even then, } \\
\text { no effect was } \\
\text { observed. }\end{array}$ & $\begin{array}{c}\oplus \oplus \bigcirc \bigcirc \\
\text { LOW }\end{array}$ & $\begin{array}{c}215 / 215 \\
(100.0 \%)\end{array}$ & $\begin{array}{c}215 / 215 \\
(100.0 \%)\end{array}$ & $\begin{array}{c}-1.46-- \\
(-9.61 \text { to } 6.70)\end{array}$ \\
\hline
\end{tabular}


Table 2 (cont.). Profile of the quality of evidence for the results of observational studies, adapted from GRADE.

Wake After Sleep Onset - Waso

\begin{tabular}{|c|c|c|c|c|c|c|c|c|c|}
\hline $\begin{array}{c}430 \\
\text { (3 observational } \\
\text { studies) }\end{array}$ & $\underset{a, c, e}{\text { serious }}$ & serious ${ }^{b}$ & not serious & not serious & $\begin{array}{l}\text { all the } \\
\text { confounding } \\
\text { factors } \\
\text { suggested as a } \\
\text { spurious effect } \\
\text { and yet no } \\
\text { effect was } \\
\text { observed. }\end{array}$ & $\begin{array}{c}\oplus \oplus \oplus \bigcirc \\
\text { MODERATE }\end{array}$ & $\begin{array}{l}215 / 215 \\
(100.0 \%)\end{array}$ & $\begin{array}{c}215 / 215 \\
(100.0 \%)\end{array}$ & $\begin{array}{c}-32.61-- \\
(-34.98 \text { to }-30.24)\end{array}$ \\
\hline \multicolumn{10}{|c|}{ Sleep Efficiency } \\
\hline $\begin{array}{c}430 \\
\text { (3 observational } \\
\text { studies) }\end{array}$ & $\underset{a, c, e}{\text { serious }}$ & serious $^{b}$ & not serious & not serious & $\begin{array}{l}\text { all potential } \\
\text { confounding } \\
\text { factors would } \\
\text { suggest a } \\
\text { spurious effect, } \\
\text { and even then, } \\
\text { no effect was } \\
\text { observed. }\end{array}$ & $\begin{array}{c}\oplus \oplus \oplus \bigcirc \\
\text { MODERATE }\end{array}$ & $\begin{array}{c}215 / 215 \\
(100.0 \%)\end{array}$ & $\begin{array}{c}215 / 215 \\
(100.0 \%)\end{array}$ & $\begin{array}{c}3.66-- \\
(3.02 \text { to } 4.30)\end{array}$ \\
\hline
\end{tabular}

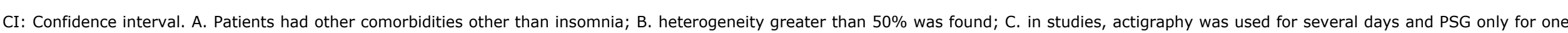
night; D. wide confidence interval; E. subjective report used 


\section{DISCUSSION}

The findings showed that ACT approached PSG only when verifying SL. It presented average and confidence intervals narrow enough to affirm that ACT can be used with confidence in the clinical analysis of this parameter with the objective to identify the sleep patterns of adults with insomnia.

When comparing the ACT's TTS, it is underestimated, with an average of 46 min compared to the PSG, with a significant difference between the two technologies. Thus, the evaluated technologies presented different information when evaluating the TTS. On the other hand, another study, with high evidence quality, found an average difference of 10.14 min between the two technologies, demonstrating that ACT can be safely used to assess the TTS of these individuals with insomnia ${ }^{16}$. Another study, however carried out with healthy adults, when comparing ACT with PSG to assess TTS, also found high reliability to be used in the objective measurement of this parameter ${ }^{10}$.

When evaluating $S L$, we found a narrow confidence interval ( $95 \% \mathrm{CI}:-9.61$ to $6.70 \mathrm{~min}$ ) with an average difference of -1.46 min. Thus, ACT provides SL information that is true enough to be used as the only objective measure of sleep. Another study, when meta-analyzing 12 manuscripts to assess SL in a patient with insomnia, also found a narrow difference between ACT and PSG, with an 
average of 6.17 min agreeing with our study when stating that ACT can be used safely in the measure of this parameter ${ }^{16}$.

In the meta-analysis applied to WASO it was found an underestimation of ACT in relation to PSG in the measurement of this sleep parameter, with an average of $32.61 \mathrm{~min}$. Therefore, based on this finding, the ACT did not show clinical confidence for this outcome. Another study, also in its analysis, found a clinically extensive interval between the two technologies, with possible average differences of $33.22 \mathrm{~min}$, not indicating $\mathrm{ACT}$ as reliable as WASO to provide an objective assessment ${ }^{16}$.

The findings of this study were corroborated by a wide range of difference found between PSG and ACT for assessing $\mathrm{SE}$, a $1 \%$ level, with the quality of its evidence being considered moderate ${ }^{16}$. In the present study, it was also found low reliability in measuring of the sleep by ACT compared to PSG, with an average difference of $3.66 \%$. A different study, carried out with healthy population, also found actigraphy measures of SE different from the PSG's ${ }^{10}$.

ACT when compared to PSG has several benefits, such as: not requiring a sleep technician to use the device; easy recording of sleep for several consecutive days; low costs; it can be used in the individual's natural environment and it has greater ability to obtain reliable estimates of sleep parameters when patients may not be able to report them. Skin irritation is the only damage reported from using the 
actigraphy but is considered mild when assessing its potential benefits ${ }^{17}$.

The main limitation of this study was the quality of the evidence from the studies selected for this review, in addition to the high heterogeneity found in the meta-analysis. Besides, a tendency to most compare only one night of PSG records against several nights recorded with ACT was noticed, which can lead to greater bias associated with the effect of the first night due to the intrusive nature of the medication used in the PSG.

Other limitations found were the use of personalized measures of ACT and the fact that patients have comorbidities other than insomnia in some studies, which can cause information bias and heterogeneity. These limitations downgraded the quality of the evidence to moderate and low.

\section{CONCLUSION}

Based on this study, we concluded that ACT can be useful in assessing SL in patients with insomnia, providing a consistent measure with PSG. Although ACT showed differences in the assessment of TTS, WASO, and SE, the benefits of its use must be taken into account.

However, to affirm that these technologies are equivalent in terms of effectivity, more research is needed. Understanding the differences between the two tools and addressing specific factors that may impact these 
divergences will ensure greater safety in the clinical analysis of patients and in decision making. Such research efforts are likely to strengthen the available evidence.

\section{REFERENCES}

1.Buysse DJ. Insomnia. JAMA Neurol 2013;309:706-16. https://doi.org/10.1001/jama.2013.193

2.Sateia MJ, Buysse DJ, Krystal AD, Neubauer DN, Heald JL. Clinical practice guideline for the pharmacologic treatment of chronic insomnia in adults: an American Academy of Sleep Medicine clinical practice guideline. J Clin Sleep Med 2017;309:307-49. https://doi.org/10.5664/jcsm.6470

3. American Psychiatric Association. Diagnostic and statistical manual of mental disorders. 5th ed. 2013.

4.DiBonaventura M, Richard L, Kumar M, Forsythe A, Flores NM, Moline $M$. The association between insomnia and insomnia treatment side effects on health status, work productivity, and healthcare resource use. Plos ONE 2015;10: e0137117. https://doi.org/10.1371/journal.pone.0137117

5. Hägg SA, Torén K, Lindberg E. Role of sleep disturbances in occupational accidents among

women.

Scand J Work Environ Health 2015;41:368-76.

https://doi.org/10.5271/sjweh.3495

6. Bathgate CJ, Edinger JD, Wyatt JK, Krystal AD. Objective but not subjective short sleep duration associated with increased risk for hypertension in individuals with insomnia. Sleep 2016;39:1037-45. https://doi.org/10.5665/sleep.5748

7. Bhaskar S, Hemavathy D, Prasad S. Prevalence of chronic insomnia in adult patients and its correlation with medical comorbidities. J Family Med Prim Care 2016;5:780. https://doi.org/10.4103/22494863.201153

8. Neves GSML, Macedo P, Gomes MM. Transtornos do sono: atualização (1/2). Bras Neurol 2017;53:19-30.

http://docs.bvsalud.org/biblioref/2017/12/876873/rbn-533-3-

transtornos-do-sono-1-2.pdf

9. Marino M, Li Y, Rueschman MN, Winkelman JW, Ellenbogen JM, Solet JM, et al. Measuring sleep: accuracy, sensitivity, and specificity of wrist actigraphy compared to polysomnography. Sleep 2013;36:1747-55. https://doi.org/10.5665/sleep.3142

10.Mantua J, Gravel N, Spencer RM. Reliability of Sleep Measures from Four Personal Health Monitoring Devices Compared to Research-Based Actigraphy and Polysomnography. Sensors (Basel) 2016;16:E646. https://doi.org/10.3390/s16050646 
11. Withrow D, Roth T, Koshorek G, Roehrs T. Relation between ambulatory actigraphy and laboratory polysomnography in insomnia practice and research. J Sleep Res 2019;28:e12854. https://doi.org/10.1111/jsr.12854

12.Perlis M, Zee J, Swinkels C, Kloss J, Morgan K, Davidet B, et al. The Incidence and Temporal Patterning of Insomnia: A 2nd Study. J Sleep Res 2014;23:499-507. https://doi.org/10.1111/jsr.12150

13. Buysse DJ, Cheng Yu, Germain A, Moul DE, Franzen PL, Fletcher M, et al. Night-to-night sleep variability in older adults with and without chronic insomnia. Sleep Med 2010;11:56-64.

https://doi.org/10.1016/j.sleep.2009.02.010

14.Ministério da saúde. Diretrizes metodológicas do sistema GRADE: manual de graduação da qualidade da evidência e força de recomendação para tomada de decisão em saúde (endereço na internet). 2014 (accessed: 2020). Available from: http://bvsms.saude.gov.br/bvs/publicacoes/diretrizes metodologicas sistema grade.pdf

15.Moher D, Liberati A, Tetzlaff J, Altman DG. Preferred Reporting Items for Systematic Reviews and Meta-Analyses: The PRISMA Statement. PLoS Med 2009;6:e1000097. https://doi.org/10.1371/journal.pmed.1000097

16.Smith MT, McCrae CS, Cheung J, Martin JL, Harrod CG, Heald JL, et al. Use of actigraphy for the evaluation of sleep disorders and circadian rhythm sleep-wake disorders: an American Academy of Sleep Medicine clinical practice guideline. J Clin Sleep Med 2018;14:1231-7. https://doi.org/10.5664/jcsm.7228

17. Kapella MC, Vispute S, Zhu B, Herdegen JJ. Actigraphy scoring for sleep outcome measures in chronic obstructive pulmonary disease. Sleep Med 2017;37:124-9.

https://doi.org/10.1016/j.sleep.2017.06.012

18. Mundt JM, Crew EC, Krietsch K, Roth AJ, Vatthauer K, Robinson $\mathrm{ME}$, et al. Measuring treatment outcomes in comorbid insomnia and fibromyalgia: concordance of subjective and objective assessments. J Clin Sleep Med 2016;12:215-23. https://doi.org/10.5664/jcsm.5488

19.Jeon S, Conley S, Redeker NS. Discrepancy between wristactigraphy and polysomnographic measures of sleep in patients with stable heart failure and a novel approach to evaluating discrepancy. J Sleep Res 2019;28:e12717. https://doi.org/10.1111/jsr.12717

20. Williams JM, Taylor DJ, Slavish DC, Gardner CE, Zimmerman MR, Patel $\mathrm{K}$, et al. Validity of actigraphy in young adults with insomnia. Behav Sleep Med 2020;18:91-106. https://doi.org/10.1080/15402002.2018.1545653

21.Choi SJ, Kang M, Je Sung M, Yeon Joo E. Discordant sleep parameters among actigraphy, polysomnography, and perceived sleep in patients with sleep-disordered breathing in comparison with patients with chronic insomnia disorder. Sleep Breath 2017;21:83743. https://doi.org/10.1007/s11325-017-1514-5 